\title{
Problems Perceived by Livestock Farmers in Utilization of Livestock Extension Services of Animal Husbandry Department in Jammu District of Jammu \& Kashmir, India
}

\author{
Avinash Neeraj ${ }^{*}$ and Pranav Kumar
}

\begin{abstract}
Division of Veterinary and Animal Husbandry Extension Education, Faculty of Veterinary Sciences \& Animal Husbandry, R. S. Pura, SKUAST-Jammu (J \& K), India
\end{abstract}

*Corresponding author

\begin{tabular}{l} 
Ke y w or d s \\
$\begin{array}{l}\text { Problems, SDAH, } \\
\text { Livestock extension } \\
\text { services, Livestock } \\
\text { farmers, VASs }\end{array}$ \\
\hline Article Info \\
$\begin{array}{l}\text { Accepted: } \\
\text { 10 January } 2018 \\
\text { Available Online: } \\
\text { 10 February } 2018\end{array}$ \\
\hline
\end{tabular}

\section{Introduction}

Livestock plays an important role in Indian economy. About 20.5 million people depend upon livestock for their livelihood. Livestock contributed $16 \%$ to the income of small farm households as against an average of $14 \%$ for all rural households. Livestock provides livelihood to two-third of rural community. It also provides employment to about $8.8 \%$ of the population in India (Annual Report 2014-
The study examines the problems of livestock farmers in accessing the livestock extension services of Animal Husbandry department of Jammu district of J \& K state. The data was collected from 12 randomly selected villages in 4 blocks of Jammu district. 10 livestock farmers from each village and five Veterinary Assistant Surgeons (VASs) from each blocks selected making a total of 120 livestock farmers and 20 Veterinary Assistant Surgeons (VASs) i.e., field level functionaries of department of Animal Husbandry, Jammu. Socio-personal and socio economic profile of the respondents reveals that majority of the livestock farmers were old aged (59.17\%), illiterate (35.83\%) belongs to nuclear family $(70 \%)$ and land holding less than 5 acres $(60 \%)$. Major 'serious' problems faced by the livestock farmers were 'Non-availability of round the clock extension advisory services by State Department of Animal Husbandry'. Problems faced by VASs in performing extension activities were Lack of sufficient infrastructure facilities for conducting extension activities', 'negligible budget allotment for carrying out regular extension activities' etc. The study concludes that role of extension delivery system of Animal Husbandry Department, Jammu of J\& K state needs improvement and could be changed, modified and boosted up by effective policy making.

A B S T R A C T 
other provinces of India due to poor management and poor breed selection and lack of extension delivery system (Baba et al., 2011). This could be attributed to illiteracy and lack of knowledge of the people regarding livestock. Livestock is an essential part of the socio-economic structure of rural India as it provides draught power, manure and energy. Livestock production can be improved by better extension services, proper management and effective disease control programme (Moaeen-u-Din and Babar, 2006). It is utmost necessary to increase the livestock production by using modern technologies in order to meet its growing demand, rapid increase in population and to earn foreign exchange. Demand driven extension approach for services is bound to strengthen functional relationship between different extension agencies and they will jointly work on a common platform for providing the demanded services (Qamar, 2004). The activities relating to livestock extension are sporadic and spread over time and space and do not meet the requirement of a vast majority of farmers (Lehmann et al., 1994). Farmer needs information to change their level of awareness, attitude and ultimately the practice, in order to improve the existing situation. The present production level of livestock is quite low and inadequate allocation of both development and non-development funds to this sector by the government and scarcity of suitably trained man power are some of its major constraints (Ullah, 1998). The livestock extension delivery by dairy cooperatives in developing countries is getting attention during the past decade since they are very helpful in overcoming access barriers to assets, information, services, and the markets for small-holders (Rathod et al., 2011; Nishi et al., 2011

\section{Materials and Methods}

The study was conducted in Jammu district of J\& K state. Jammu district was divided into four clusters having two blocks each (as Jammu district comprises of eight blocks). From each cluster one block was selected at random, so a total of four blocks were selected for the study. A comprehensive list of villages of the selected blocks was prepared. Twelve villages (three villages from each block) were selected randomly from four selected blocks. 10 livestock farmers from each village and five Veterinary Assistant Surgeons (VASs) from each blocks selected making a total of 120 livestock farmers and 20 Veterinary Assistant Surgeons (VASs). Primary data were collected with the help of semi- structured interview schedule while secondary data were obtained from the department website and occasional reports of the department. Problems perceived by the livestock farmers in accessing the livestock services from the SDAH were classified into field, technical, infrastructural and institutional levels. Respondents' responses were categorized into 'serious' and 'not so serious' and ranking of the problems were done.

\section{Results and Discussion}

Socio-personal- economic profile of the respondents

On analysis of Table 1, it was found that majority of the livestock farmers were old aged $(59.17 \%)$, illiterate $(35.83 \%)$ having nuclear family $(70 \%)$ and land holding less than 5 acres $(60 \%)$.

Problems of the livestock farmers in utilization of livestock extension services of SDAH

On perusal of Table 2, it was found that among the "field level problems" faced by livestock keepers 'Non-availability of round the clock extension services by the SDAH' was found to be the most 'serious' problems and it was ranked first by majority $(83.33 \%)$ of respondents followed by 'Lack of time with 
veterinarians to provide extension related information and services' (57.50\%), 'Veterinary dispensaries are at far off distances from the villages' (50.00\%), and 'Lack of information about insurance facilities for the animals'(31.67\%) were the other problems.

Similar findings were reported by many other researchers such as Venkatadri (2002) reported that "Veterinary functionaries are expected to perform twenty-five multifarious activities in which extension is one' and Ravi Kumar (2005) too observed that 'The State Departments of Animal Husbandry (SDAH) the major stakeholders for the livestock development in India is mostly dominated by animal health concerns with negligible attention to production related advice to farmers and their spending on livestock extension activities is only around 1-3\% of their total budget.

About 76.67 percent of respondents were of the view that 'Impolite behavior of veterinary staff towards livestock farmers' was not the serious problem.

Similarly, on perusal of Table 3, it was found that among the "technical problems" faced by livestock keepers 'In adequate extension related materials i.e input availability (material to be distributed free of cost) for conducting extension education programmes in rural areas' was found to be the most 'serious' problems and it was ranked first by the greater majority (99.17\%) respondents followed by 'Lack of skills on part of veterinarians in providing the extension activities/services' $(70.83 \%)$, 'Inadequate veterinary staff and larger area to be covered'(70.00\%). Similar opinions were conveyed by Chander et al., (2010) and mentioned in his review paper on livestock technology transfer service in India that the livestock sector is still considered as subsidiary to crop sector (where, lots of free inputs used to be distributed) and the extension format and methodology developed for crop production are considered to take care of the livestock extension needs. It was also observed from the Table 3 that livestock farmers perceived about the field functionaries (mainly the VASs) were not providing information on newly developed livestock production technologies because of inefficiency or lack of training of the veterinarians in providing the extension services and information.

The results are in conformity with that of (Ravikumar, 2005) who reported that insufficient supply of extension content to the hospitals, lack of facilities for doing extension camps in villages, inadequate distribution of leaflet to the farmers, non-availability of fodder seeds at the veterinary hospitals, inadequate budget allotment for the provision of extension services, non-availability of round the clock services as the major problems perceived by livestock farmers in utilization of veterinary services.

Rajput (2006) also identified the problems like insufficient supply of extension content to the hospitals and poor accessibility of timely veterinary services as the major perceived problems of livestock farmers. Hence, the government authorities should make earnest efforts to solve these constraints so as to make livestock extension delivery effective.

Also, it is evident from Table 4, that among the "infrastructural problems" faced by livestock keepers 'Lack of sufficient infrastructure facilities for conducting extension activities' was found to be the most 'serious' problems and it was ranked first by the greater majority $(99.17 \%)$ respondents followed by 'Lack of facilities for doing extension camps in villages' (86.67 \%), 'Lack of transport facilities for conducting extension in the villages' $(85.00 \%)$. 
Table.1 Socio-personal- economic profile of the livestock farmers $(n=120)$

\begin{tabular}{|c|c|c|c|c|}
\hline S. No. & Variables & Category & Frequency & Percentage \\
\hline 1. & Age & $\begin{array}{l}\text { Young }(<35 \text { yrs }) \\
\text { Middle }(35-50 \text { yrs }) \\
\text { Old }(>50 \text { yrs })\end{array}$ & $\begin{array}{l}05 \\
44 \\
71\end{array}$ & $\begin{array}{c}4.17 \\
36.66 \\
59.17\end{array}$ \\
\hline 2. & Education & $\begin{array}{l}\text { Illiterate } \\
\text { Primary } \\
\text { Middle class } \\
\text { High school } \\
\text { Above high school }\end{array}$ & $\begin{array}{l}43 \\
07 \\
21 \\
33 \\
16\end{array}$ & $\begin{array}{c}35.83 \\
5.83 \\
17.50 \\
27.50 \\
13.33\end{array}$ \\
\hline 3. & Type of family & $\begin{array}{l}\text { Nuclear } \\
\text { Joint }\end{array}$ & $\begin{array}{l}84 \\
36\end{array}$ & $\begin{array}{l}70 \\
30\end{array}$ \\
\hline 4. & Land holding & $\begin{array}{l}\text { Landless } \\
\text { Marginal }(<2.5) \\
\text { Small }(2.5-5) \\
\text { Medium }(5-10) \\
\text { Large }(>10)\end{array}$ & $\begin{array}{c}34 \\
66 \\
17 \\
03 \\
-\end{array}$ & $\begin{array}{c}28.33 \\
55.00 \\
14.17 \\
2.50 \\
-\end{array}$ \\
\hline
\end{tabular}

Table.2 Field level problems of the livestock farmers in utilization of livestock extension delivery of SDAH

\begin{tabular}{|c|c|c|c|c|}
\hline \multirow{2}{*}{$\begin{array}{l}\text { S. } \\
\text { No. }\end{array}$} & \multirow[t]{2}{*}{ Field level problems } & Serious & Not so serious & \multirow[t]{2}{*}{ Rank } \\
\hline & & $\%$ & $\%$ & \\
\hline 1 & $\begin{array}{l}\text { Non-availability of round the clock extension services at } \\
\text { SDAH }\end{array}$ & $83.33(100)$ & $16.67(20)$ & I \\
\hline 2 & $\begin{array}{l}\text { Veterinary dispensaries are at far off distances from the } \\
\text { villages }\end{array}$ & $50.00(60)$ & $50.00(60)$ & III \\
\hline 3 & Lack of information about insurance facilities for the animals & $31.67(38)$ & $68.33(82)$ & IV \\
\hline 4 & Impolite behavior of veterinary staff towards livestock farmers & $23.33(28)$ & $76.67(92)$ & $\mathrm{V}$ \\
\hline 5 & $\begin{array}{l}\text { Lack of time with veterinarians to provide extension related } \\
\text { information and services }\end{array}$ & $57.50(69)$ & $42.50(51)$ & II \\
\hline
\end{tabular}

Table.3 Technical problems of the livestock farmers in utilization of livestock extension delivery of SDAH

\begin{tabular}{|l|l|l|l|l|}
\hline S. No. & Technical problems & Serious & Not so serious & Rank \\
\hline 1 & $\begin{array}{l}\text { In adequate extension related materials i.e input availability } \\
\text { (material to be distributed free of cost) for conducting } \\
\text { extension education programmes in rural areas }\end{array}$ & $99.17(119)$ & $0.83(01)$ & I \\
\hline $\mathbf{2}$ & $\begin{array}{l}\text { Inadequate veterinary staff and larger area to be covered } \\
\begin{array}{l}\text { Lack of skills on part of veterinarians in providing the } \\
\text { extension activities/services }\end{array}\end{array}$ & $70.00(84)$ & $30.00(36)$ & III \\
\hline $\begin{array}{l}\text { Lack of providing information on newly developed } \\
\text { livestock production technologies }\end{array}$ & $25.00(30)$ & $75.00(90)$ & V \\
\hline $\mathbf{l}$ & $\begin{array}{l}\text { Inefficiency of the veterinarians in providing the extension } \\
\text { services }\end{array}$ & $15.00(18)$ & $85(102)$ & VI \\
\hline $\begin{array}{l}\text { Non-availability of extension staff for providing exclusively } \\
\text { extension information }\end{array}$ & $67.50(81)$ & $32.50(39)$ & \\
\hline 6
\end{tabular}


Table.4 Infrastructural problems of the livestock farmers in utilization of livestock extension delivery of SDAH

\begin{tabular}{|c|c|c|c|c|}
\hline \multirow[t]{2}{*}{ S. No. } & \multirow[t]{2}{*}{ Infrastructural problems } & Serious & $\begin{array}{l}\text { Not so } \\
\text { serious }\end{array}$ & \multirow[t]{2}{*}{ Rank } \\
\hline & & $\%$ & $\%$ & \\
\hline 1 & $\begin{array}{l}\text { Lack of sufficient infrastructure facilities for conducting } \\
\text { extension activities }\end{array}$ & $99.17(119)$ & $0.83(01)$ & I \\
\hline 2 & Lack of facilities for doing extension camps in villages & $86.67(104)$ & $13.33(16)$ & II \\
\hline 3 & $\begin{array}{l}\text { Non-availability of techniques for technology transfer at } \\
\text { the veterinary hospitals }\end{array}$ & $71.67(86)$ & $28.33(34)$ & IV \\
\hline 4 & $\begin{array}{l}\text { Lack of transport facilities for conducting extension } \\
\text { programs in the villages }\end{array}$ & $85.00(102)$ & $15.00(18)$ & III \\
\hline
\end{tabular}

Table.5 Institutional problems of the livestock farmers in utilization of livestock extension delivery of SDAH

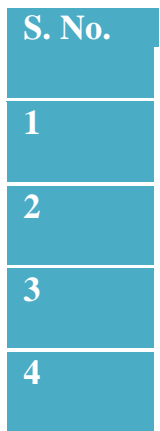

Institutional problems
Inadequate/ negligible budget allotment for carrying out
regular of extension activities
Lack of accountability among veterinarians for
providing the extension activities/services
Fee charged by the veterinary staff for free extension
services
Irregularity of veterinary staff in conducting the
extension programmes.

\begin{tabular}{|c|c|c|}
\hline Serious & Not so serious & Rank \\
\hline$\%$ & $\%$ & \\
\hline 100.00 (120) & - & I \\
\hline $80.00 \quad(96)$ & $20.00(24)$ & II \\
\hline $17.50 \quad(21)$ & $82.50(99)$ & IV \\
\hline $31.67 \quad(38)$ & $68.33(82)$ & III \\
\hline
\end{tabular}

Table.6 Distribution of VASs according to the problems faced (field level) in performing extension activities

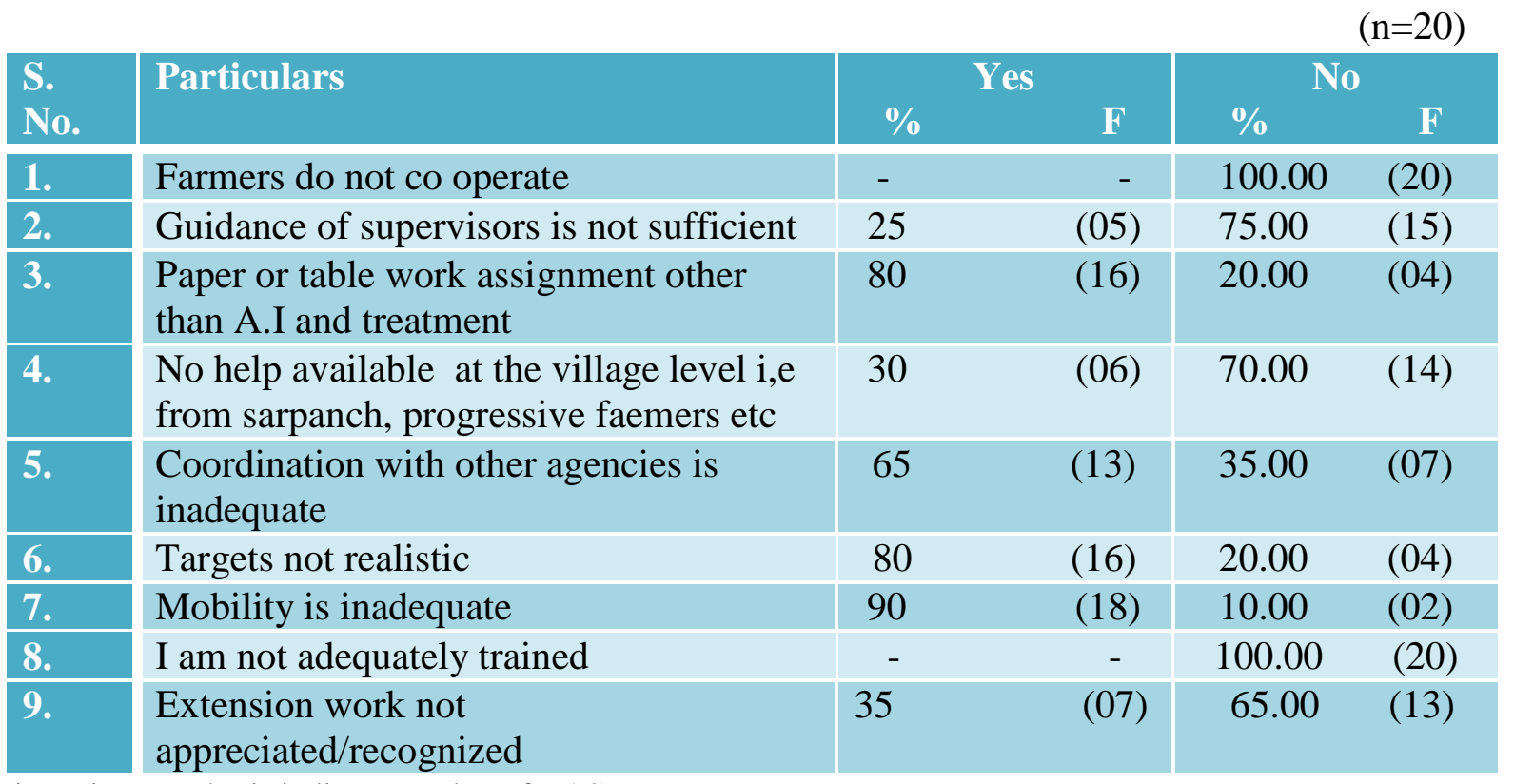

Figure in parenthesis indicate number of VASs 
Table.7 Distribution of VASs according to the problems faced (official level) while performing extension activities

\begin{tabular}{|c|c|c|c|c|c|}
\hline S. No & Reasons & \multicolumn{2}{|c|}{ Yes } & \multicolumn{2}{|c|}{ No } \\
\hline & & $\%$ & $\mathbf{F}$ & & $\mathbf{F}$ \\
\hline 1 & Heavy work load & 80 & (16) & 20 & (4) \\
\hline 2 & $\begin{array}{l}\text { Shortage of trained manpower like LAs } \\
\text { (Livestock Assistants ) for extension } \\
\text { activities }\end{array}$ & 90 & (18) & 10 & (2) \\
\hline 3 & $\begin{array}{l}\text { Shortage of extension activities related } \\
\text { context }\end{array}$ & 80 & (16) & 20 & (4) \\
\hline 4 & $\begin{array}{l}\text { Shortage of budgets for extension } \\
\text { activities }\end{array}$ & 80 & (16) & 20 & (4) \\
\hline
\end{tabular}

Figure in parenthesis indicate number of VASs

Based on the findings of Table 5, it was found that among the "institutional problems" faced by livestock keepers 'Inadequate/ negligible budget allotment for carrying out regular extension activities' was found to be the most 'serious' problems and it was ranked first by 100 per cent of respondents followed by 'Lack of accountability among veterinarians for providing the extension activities/services' $(80.00 \%)$, 'Irregularity of veterinary staff in conducting the extension programmes' (31.67 $\%$ ) were other problems. Similar observation was reported by Joshi (2017) and she commented that only one centrally sponsored scheme on "Livestock extension and delivery services" with a budgetary outlay of Rs.15.00 crore was proposed by Department of Animal Husbandry, Dairying and Fisheries (DAHDF) during the 11th plan period and to cater the diverse needs of livestock farmers, an efficient livestock extension education system is required.

\section{Problems experienced by Veterinary Assistant Surgeons (VASs) in performing extension activities}

The VASs were enquired regarding the "field level problems" they were experiencing in performing extension activities and the results were tabulated (Table 6). The top most problems the VASs felt while executing the extension activities was 'inadequate mobility' (90\%), 'various assignments other than A.I and treatment' $(80 \%)$ and 'targets not realistic' $(80 \%)$. The other problems felt by VASs include 'inadequate coordination with other agencies' $(65 \%)$ and extension work not appreciated (35\%). These findings were in agreement with the findings of Budak and Yurdakul (2004). Extension agents need to be very mobile to touch as many clienteles as possible (Adeokun and Akinyemi, 2003).

The VASs were also enquired regarding the "official level problems" they were experiencing in performing extension activities and the result was tabulated in Table 7. The top most problem VASs felt while executing the extension activities include 'shortage of man power' $(90 \%)$ followed by 'shortage of extension activities related content' $(80 \%)$, 'heavy work load' $(80 \%)$ and 'shortage of budgets for extension activities' (80\%).

The study entitled "Problems Perceived by Livestock Farmers in Utilization of Livestock Extension Services of Animal Husbandry Department" was undertaken in Jammu District of Jammu \& Kashmir state. It was found that lack of infrastructure, inadequate 
budget allocation and poor message delivery system towards extension education were the characteristics of state department of Animal Husbandry, Jammu. The SDAH, Jammu were primarily catering to animal health and breeding needs, whereas, there was no clear cut mandate specifically towards extension education activities for livestock development. The grassroot level extension functionaries considered the extension activities as low profile and thankless job. Major 'serious' problems faced by the livestock farmers were 'Non-availability of round the clock extension advisory services by State Department of Animal Husbandry'. Problems faced by VASs in performing extension activities were lack of sufficient infrastructure facilities for conducting extension activities', 'negligible budget allotment for carrying out regular extension activities' etc. The study concludes that role of extension delivery system of Animal Husbandry Department, Jammu of J \& K state needs improvement and could be changed, modified and boosted up by effective policy making.

\section{Acknowledgment}

This study was conducted in Jammu district of Jammu and Kashmir state. Authors are thankful to the all the livestock farmers who participated in the survey and had given precious time and relevant information for this study. Authors are also thankful to officers of State Department of Animal Husbandry, Jammu and Veterinary Assistant Surgeons posted in different blocks of Jammu district for giving time and support from their busy schedule in carrying out this research.

\section{References}

Adeokun, O.A. and Akinyemi, J.O. 2003. Assessment of veterinary extension services to livestock farmers in Egba Division. African Journal of Livestock
Extension, 2:30-36.

Ahuja, V., Kurup, M. P. G., Bhasin N. R. and Joseph, A. K. 2008. Assessment and Reflections on Livestock service delivery systems in Andhra Pradesh. CALPI Programme Series 4 Inter Cooperation in India, Hyderabad

Annual Report 2014-15, Role of livestock in Indian Economy, Department of Animal Husbandry, Dairying and Fisheries, Ministry of Agriculture and Farmers Welfare, Govt. of India.

Baba, S.H., Wani, M.H. and Zargar, Bilal A. 2011. Dynamics and sustainability of livestock sector in Jammu and Kashmir. Agricultural Economics Research Review, 24: 119-132.

Budak, D.B. and Yurdakul, O. 2004. Sustainable Agricultural Development through Extension Education. Asian Journal of Plant Sciences, 3(2):215218.

Chander, M. and Rathod, P. 2015. Extension strategies for animal husbandry sector in India. Retrieved from https://www.slideshare.net on 2-7-2017.

Chander, M., Dutt, T., Ravikumar, R.K. and Subrahmanyeswari, B. 2010. Livestock technology transfer service in India: A review. Ind. J. Anim. Sci., 80(11): 111525.

Farooq, M.K. and A. Qudoos. 1999. Constraints in the Adoption of Modern Livestock Practices. Pakistan Vet. J. 19(1): 53-55.

Joshi, P. 2017. Livestock Extension Service Delivery System in India: A Review. Agric. Rural Develop. 4: 29-34

Lehmann, R., Vishva, R., Ramesh, K. S., Subramanyam, S., Ray, Nandita and Waelty, S. 1994. Bovine and Diary Development in Andhra Pradesh. Indo Swiss project, pp.14-103. Andhra Pradesh, Hyderabad.

Moaeen-ud Din, M. and M.E. Babar. 2006. Livestock Farming in peri-urban areas 
of Faisalabad. Livestock Res. Rural Develop, 18(1) 2006.

Nishi, Sah, A. K. and Ram Kumar, 2011. Dairy farmers' satisfaction with dairy cooperative societies: A case study. Indian Res. J. Ext. Edu., 11: 74-78.

Qamar, M.K. 2004. Demand for Services Planning by Villagers. A case study from Pakistan. Annual meeting of Neuchatel Initiative Group, held at Aarhus, Denmark, 2-3 November, 2004.

Rajput, D.S. 2006. Animal health delivery system among pastoralists in arid zone of Rajasthan. Ph.D. thesis. Indian Veterinary Research Institute, Izatnagar, India.

Rao, S.V.N., Ramkumar, S. and Kevin, Waldie. 2002. Dairy farming by landless women in southern states of India. In: Morrenhof, Jan., Ahuja, Vinod and Tripathy, Ashok. (eds.), Livestock services and the poor. pp 7386.

Rathod, P., Nikam, T. R., Landge, S. and Hatey, A. 2011. SWOT Analysis of Dairy Cooperatives: A Case Study of Western Maharashtra. Int. J. Res. Comm. Managem., 2 (8): 35-41.

Ravikumar, R.K. 2005. 'Livestock extension activities under the State Departments of Animal Husbandry in India: An institutional analysis. 'Ph.D. thesis, Indian Veterinary Research Institute, Izatnagar. pp. 146

Shweta, K. 2014. Artificial Insemination for Dairy Development in Ranchi District of Jharkhand. Indian Res. J. Ext. Edu. 14 (1): 90-92.

Thammiraju, D., Pochaiah, M. and Krishna Reddy, G.V. 1993. Adoption of recommended practices by farmers rearing cross bred cows. J. Rural Develop. 12(1):109-114.

Ullah, E. 1998. The Study of Small holders Milk Production in the Central Punjab and Strategies for an Effective Development Approach. MSc Thesis, Department of Livestock Management, University of Agriculture, Faisalabad.

Venkatadri, S. 2002. Technology adoption in Livestock Sector for poverty alleviation: constraints and prospects. Proceedings of national seminar on rural technology and poverty alleviation. January, National Institute of Rural Development (NIRD), Hyderabad

\section{How to cite this article:}

Avinash Neeraj and Pranav Kumar. 2018. Problems Perceived by Livestock Farmers in Utilization of Livestock Extension Services of Animal Husbandry Department in Jammu District of Jammu \& Kashmir. Int.J.Curr.Microbiol.App.Sci. 7(02): 1106-1113. doi: https://doi.org/10.20546/ijcmas.2018.702.138 